\title{
Taxonomic resolution and Biological Traits Analysis (BTA) approaches in estuarine free-living nematodes
}

\author{
A.S. Alves ${ }^{\mathrm{a}, \mathrm{b}, *}$, H. Veríssimo ${ }^{\mathrm{a}}$, M.J. Costa ${ }^{\mathrm{b}}$, J.C. Marques ${ }^{\mathrm{a}}$ \\ a IMAR - Institute of Marine Research, Department of Life Sciences, Faculty of Sciences and Technology, University of Coimbra, 3004-517 Coimbra, Portugal \\ ${ }^{\mathrm{b}}$ Centro de Oceanografia, Faculdade de Ciências, Universidade de Lisboa, Campo Grande, 1749-016 Lisboa, Portugal
}

\section{A R T I C L E I N F O}

Article history:

Received 28 May 2013

Accepted 24 December 2013

Available online 4 January 2014

\section{Keywords:}

free-living nematodes

taxonomic resolution

functional groups

Biological Traits Analysis (BTA)

estuaries

\begin{abstract}
A B S T R A C T
The taxonomic and functional structure of the subtidal nematode assemblages from a temperate estuary (Mondego estuary, Portugal) was studied, focussing on different taxonomic levels (genus, family and order), on single functional groups and on multiple biological traits. Based on taxonomic levels and on four biological traits (feeding type, life strategy, tail and body shape), the analysis of the nematode assemblage distribution patterns revealed spatial differences but no clear temporal pattern. At the family and genus level, a separation of the upstream sections was observed, while a distinction of polyhaline and euhaline areas was less evident. The use of biological traits added new information regarding the relationships between diversity patterns and the environmental variables. Most nematodes encountered along the estuary were non-selective deposit feeders (1B) and omnivores/predators (2B), colonizer -persisters (score of 2 or 3 ), with clavate-conicocylindrical tails and slender bodies and with a distribution related essentially to salinity, oxygen and chlorophyll $a$. Applying a Biological Traits Analysis (BTA) showed the role of oxygen concentration in the distribution of the nematode communities. Although the BTA was no more powerful than the traditional taxonomic approach in detecting spatial differences along the Mondego estuary, it has increased our knowledge of the functional structure and characterization of nematode communities in the estuary.
\end{abstract}

(c) 2014 Elsevier Ltd. All rights reserved.

\section{Introduction}

Increasing pressures on marine ecosystems have been observed worldwide as a result of multiple natural and/or anthropogenic stressors (Dauvin, 2007). The need for scientific advice and legislation on ecosystem-based approaches to protect, conserve and manage the marine environment has never been greater (Schratzberger, 2012). It is essential that policy and decisionmakers can effectively interpret the results of applied research, meeting the requirements of society for more comprehensive information regarding environmental issues (Lubchenco, 1998).

Among the biological components, meiobenthic communities can be valuable in analysing the response to natural and disturbance gradients (Schratzberger, 2012). Free-living nematodes present several advantages for their use as monitoring organisms (Kennedy and Jacoby, 1999; Schratzberger et al., 2000; Alves et al., 2013). In addition to being highly abundant, they play an important

\footnotetext{
* Corresponding author. IMAR - Institute of Marine Research, Department of Life Sciences, Faculty of Sciences and Technology, University of Coimbra, 3004-517 Coimbra, Portugal.

E-mail address: asalves@uc.pt (A.S. Alves).
}

role as intermediaries between the microbial/detrital compartment and larger organisms (Danovaro et al., 2007) and their infaunal lifestyle has a strong influence on the diversity and composition of the assemblage since they are intimately linked with the biogeochemical properties of the sediment (Heip et al., 1985; Steyaert et al., 1999). They could be considered the ideal model organism for exploring the relationship between biodiversity and ecosystem function (Danovaro et al., 2008), allowing us to address key ecological issues, whether by using a taxonomic approach or by the analysis of biological traits.

The classical methods of nematode community analyses by the aggregation of species data into higher taxonomic groups appeared to reveal, according to Warwick (1988), similar findings to those obtained by the analysis at the species level. Accordingly, Somerfield and Clarke (1995) examined the utility of estuarine nematodes in detecting impacts at higher taxonomic levels, concluding that aggregation to the level of genus produced robust interpretations, but not at higher levels. Similarly, for macrobenthic communities, analyses at higher levels might more clearly reflect gradients being less affected by natural 'nuisance' variables than species levels analyses. Although taxonomic sufficiency (the identification of taxa to a level sufficient to permit the detection of changes in stressed assemblages; Ellis, 1985) still has criticism 


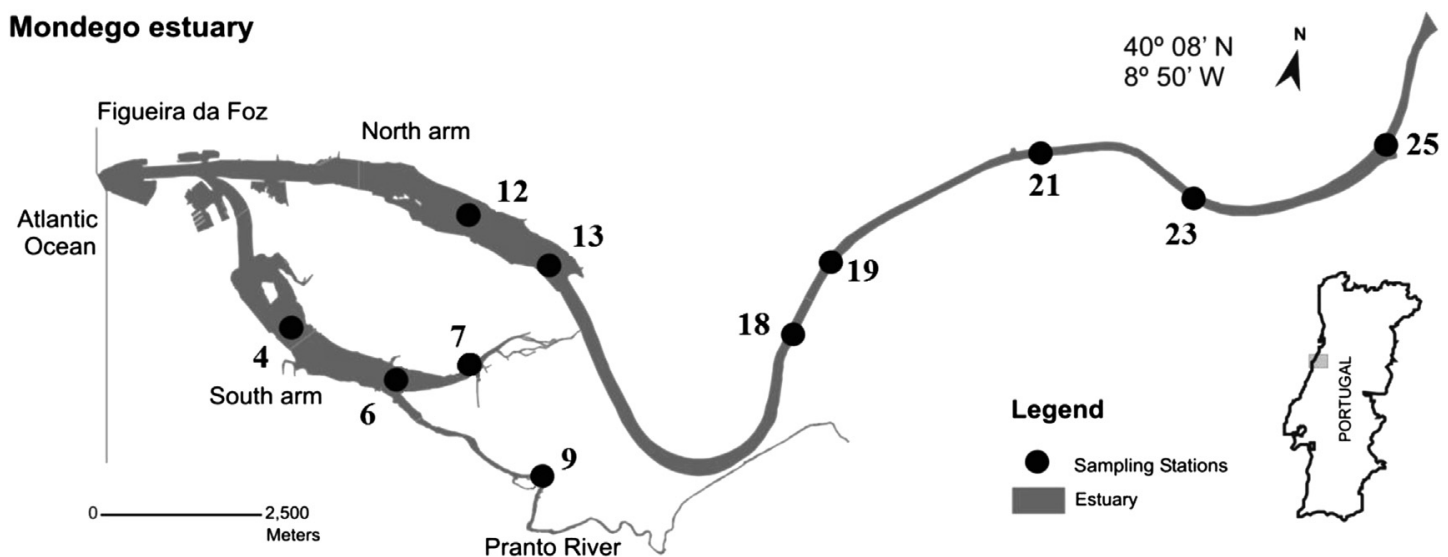

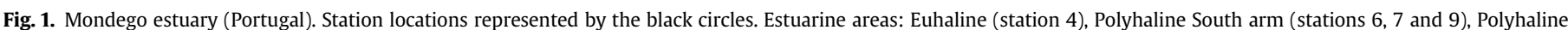
North arm (stations 12 and 13), Mesohaline (stations 18 and 19) and Oligohaline (stations 21, 23 and 25).

among the scientific community, particularly with respect to the potential losses of useful ecological information (Maurer, 2000), it allows the use of surrogate of species, such as higher taxonomic categories.

However, traditional taxonomic-based methods of nematode community analyses may not fully account for their diverse roles in ecosystem function (Schratzberger et al., 2007). It is recognized that changes in biodiversity may modify ecosystem function (Hooper et al., 2005) and taxonomic analyses alone may omit key functional aspects (Frid et al., 2000; Bremner et al., 2003). When attempting to evaluate the effects of environmental change, the inclusion of functional properties has been recommended (de Jonge et al., 2006).

According to Chalcraft and Resetarits (2003), species in functional groups share morphological traits that may represent an important ecological function. Free-living nematodes present several morphological characteristics thought to be related to important ecological functions: mouth structures (used as a proxy for feeding guilds, Wieser, 1953); tail shape (important in locomotion and reproduction, Thistle and Sherman, 1985; Thistle et al., 1995) and length-width ratio (adaptations to sedimentary environment; Jensen, 1987; Vanaverbeke et al., 2003, 2004). Furthermore, ecological characteristics such as life history strategy of nematodes (Bongers, 1990) can be informative of the condition of the habitats.

Biological Traits Analysis (BTA) takes the concept of functional groups further, aiming to describe function based on multiple traits (Bremner et al., 2003). BTA was recently applied to nematode communities of the southwestern North Sea area by Schratzberger et al. (2007). These authors used a set of five biological traits to investigate community function related to environmental variables.

Nematode assemblages have recently been studied along estuarine gradients in Portugal (Adão et al., 2009; Alves et al., 2013). In a previous study by Alves et al. (2013), the spatial and temporal biodiversity patterns of free-living nematodes in the Mondego estuary (NE Atlantic coast) were explored. Salinity and grain size composition proved to be important abiotic factors controlling the distribution of these assemblages. The present study builds on this study and analyses both taxonomic and trait information of the subtidal free-living nematode communities in the Mondego estuary, to answer three questions: (1) How valuable are different taxonomic levels in detecting spatial and temporal distribution patterns? (2) How valuable are single and multi-trait functional analyses in detecting these patterns? (3) Is there added benefit in combining functional and taxonomic approaches?

\section{Material and methods}

\subsection{Study area}

The Mondego estuary (Fig. 1), located on the western coast of Portugal $\left(40^{\circ} 08^{\circ} \mathrm{N}, 8^{\circ} 50^{\circ} \mathrm{W}\right)$, is a mesotidal system influenced by a warm-temperate climate. The estuary is a well-mixed system, some $21 \mathrm{~km}$ long with an area of approx. $8.6 \mathrm{~km}^{2}$. In its terminal part (at a distance of $7 \mathrm{~km}$ from the sea) it divides into two arms, North and South, separated by an alluvial island (Murraceira island). The two arms have different characteristics (Marques et al., 1993). The North is deeper (5-10 $\mathrm{m}$ during high tide), receives most of the system freshwater input and constitutes the main navigation channel supporting the Figueira da Foz harbour. The South is shallower $(2-4 \mathrm{~m}$ during high tide), covered by large areas of intertidal mudflats ( $75 \%$ of the area). The estuary supports several industries, salt-works, agricultural areas, mercantile and fishing harbours, thus having various anthropogenic pressures (Marques et al., 1993; Flindt et al., 1997).

\subsection{Sampling strategy, laboratory procedures and data sets}

Nematode communities were sampled on six occasions: August 2006 (Au06), November 2006 (Nv06), March 2007 (Mr07), June 2007 (Ju07), September 2009 (Sp09) and December 2009 (Dc09); at eleven stations along the estuary (Fig. 1). Stations were selected following the estuarine division proposed by Teixeira et al. (2008) based on the main water and sediment variables (salinity, sediment grain size composition and organic matter concentration) structuring benthic communities within the estuary. Five different areas covering this natural variability were sampled: Euhaline (station 4), Polyhaline South arm (stations 6, 7 and 9), Polyhaline North arm (stations 12 and 13), Mesohaline (stations 18 and 19) and Oligohaline (stations 21, 23 and 25) (Fig. 1).

\subsubsection{Environmental data}

Bottom water variables were measured in situ at each station, using an YSI Data Sonde Survey 4: salinity (except for December 2009), and dissolved oxygen $\left(\mathrm{mg} \mathrm{L}^{-1}\right)$. Additionally, water samples were collected for laboratory determination of dissolved nutrients concentration and chlorophyll $a\left(\mathrm{mg} \mathrm{m}^{-3}\right)$. Nitrates $\left(\mathrm{NO}_{3}^{-}-\mathrm{N}\right)$, nitrites $\left(\mathrm{NO}_{2}^{-}-\mathrm{N}\right)$, ammonia $\left(\mathrm{NH}_{4}^{+}-\mathrm{N}\right)$ and phosphates $\left(\mathrm{PO}_{4}^{3-}-\mathrm{P}\right)$ concentration $\left(\mu \mathrm{mol} \mathrm{L}{ }^{-1}\right)$ were analysed as described in Strickland and Parsons (1972) and in Limnologisk Metodik (1992). Chlorophyll a determinations were performed according to Parsons et al. (1985).

Sediment samples were also taken at each station to determine organic matter concentration and grain size distribution. Organic 
matter concentration was estimated as the difference between the dry sediment (at $60{ }^{\circ} \mathrm{C}$ for $72 \mathrm{~h}$ ) and the sediment weight after combustion $\left(450{ }^{\circ} \mathrm{C}\right.$ for $8 \mathrm{~h}$ ), and expressed as a percentage of total sample weight. Grain size analysis was performed by dry sieving through a column of sieves with different mesh sizes and the classification system of Brown and McLachlan (1990) was followed (gravel: $>2 \mathrm{~mm}$; coarse sand: $0.500-2.000 \mathrm{~mm}$; medium sand: $0.250-0.500 \mathrm{~mm}$; fine sand: $0.063-0.250 \mathrm{~mm}$; and silt and clay: $<0.063 \mathrm{~mm}$ ). The relative amount of the different grain-size fractions was expressed as a percentage of total sample weight. (Annex 1 - Supplementary material).

\subsubsection{Nematode data}

At each station, three replicates of subtidal sediment were collected, by inserting a Kajak corer (inner diameter: $4.6 \mathrm{~cm}$ ) $3 \mathrm{~cm}$ into the sediment. To extract the meiofauna, the sediment cores were then sieved through $1 \mathrm{~mm}$ and $38 \mu \mathrm{m}$ mesh size sieves and the fraction retained in the $38 \mu \mathrm{m}$ sieve centrifuged in Ludox HS-40 colloidal silica at a specific gravity of $1.18 \mathrm{~g} \mathrm{~cm}^{-3}$ (Vincx, 1996). The supernatant was rinsed with water and stored in a $4 \%$ buffered formalin solution. Nematodes were counted under a stereomicroscope and, from each replicate, 120 nematodes (if present) were picked out randomly and mounted on glycerin slides (Vincx, 1996). Specimens were identified to genus level using a microscope (maximum magnification $1000 \times$ ) and the keys of Platt and Warwick (1983, 1988), Warwick et al. (1998), Abebe et al. (2006) plus the online information system 'NeMys' (Steyaert et al., 2005). Family and order classification followed the classification of Lorenzen (1981) including modifications proposed by Platt and Warwick (1983, 1988). Freshwater nematodes followed the classification proposed by Abebe et al. (2006) based on De Ley and Blaxter (2004).

\subsection{Biological Traits Analysis (BTA)}

Information for assigning each taxon to a functional group was obtained from various published sources (Platt and Warwick, 1983, 1988; Warwick et al., 1998; Steyaert et al., 2005; Abebe et al., 2006). The traits selected were:

\section{A. Area}

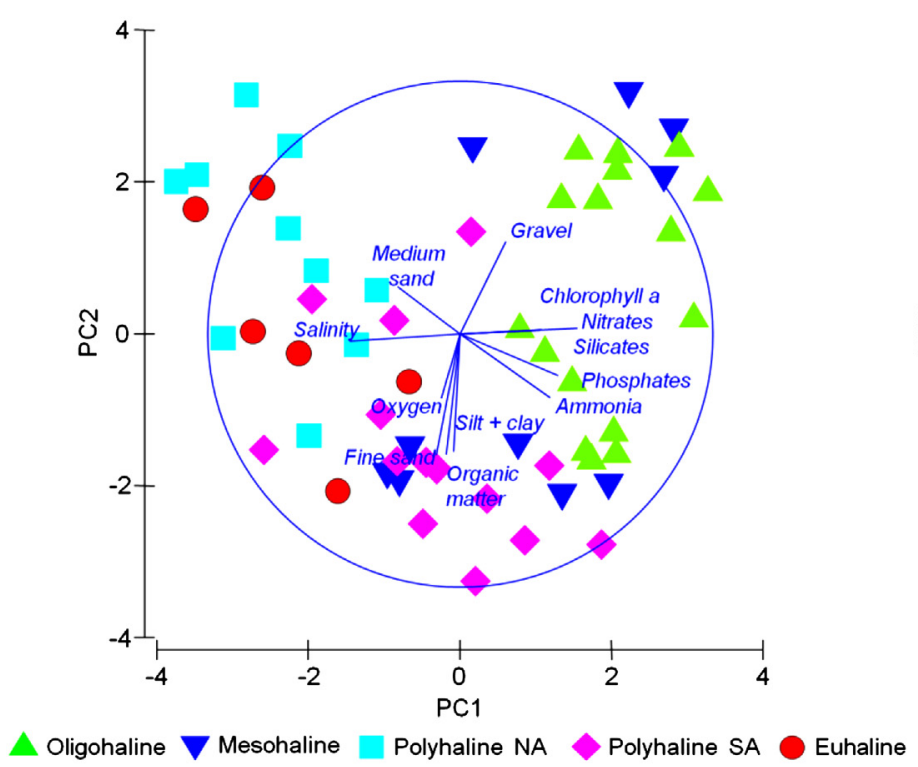

(a) Feeding type: following Wieser (1953), and based on the buccal cavity morphology, nematodes were classified as: selective deposit feeder (1A), non-selective deposit feeder (1B), epigrowth feeder (2A) and omnivore/predator (2B).

(b) Life strategy: following Bongers (1990) and Bongers et al. (1991), taxa were classified on the $\mathrm{c}-\mathrm{p}$ scale, ranging from 1 (extreme colonizers: short life cycle, high reproduction rates, tolerant to various types of disturbance) to 5 (extreme persisters: long life-cycles, few offspring, sensitive to disturbance).

(c) Tail shape: following Thistle et al. (1995), tail shape was classified as rounded (with a blunt end), clavateconicocylindrical (initially conical with an extension to the tip), conical (with a pointed tip) and long (a tail longer than five body widths).

(d) Body shape: following Soetaert et al. (2002), nematode morphology was classified as: stout, slender and long/thin.

After the traits selection, BTA computation followed the procedures described by Bremner et al. (2003, 2006a). In essence, three different numerical matrices are required: (1) 'taxa by station' (taxa density in each station); (2) 'taxa by traits' (biological traits for each taxon), and (3) 'traits by station' (biological traits in each sampling station; the cross-product of the previous two matrices). The final 'traits by station' data matrix was achieved by multiplying trait categories for each taxon present at a station by its density at that station, and then summing over all taxa present at each station to obtain a single value for each trait category in each sample (Bremner et al., 2006b). To perform the analysis, $\mathrm{R}$ environment was used ( $R$ Development Core Team, 2009) and the resulting 'traits by station' data matrix was subjected to multivariate analysis.

\subsection{Data analysis}

Multivariate analyses of biological and environmental data were performed using PRIMER v6 software package (Clarke and Gorley, 2006) with the PERMANOVA add-on (Anderson et al., 2008).

\section{B. Sampling occasion}

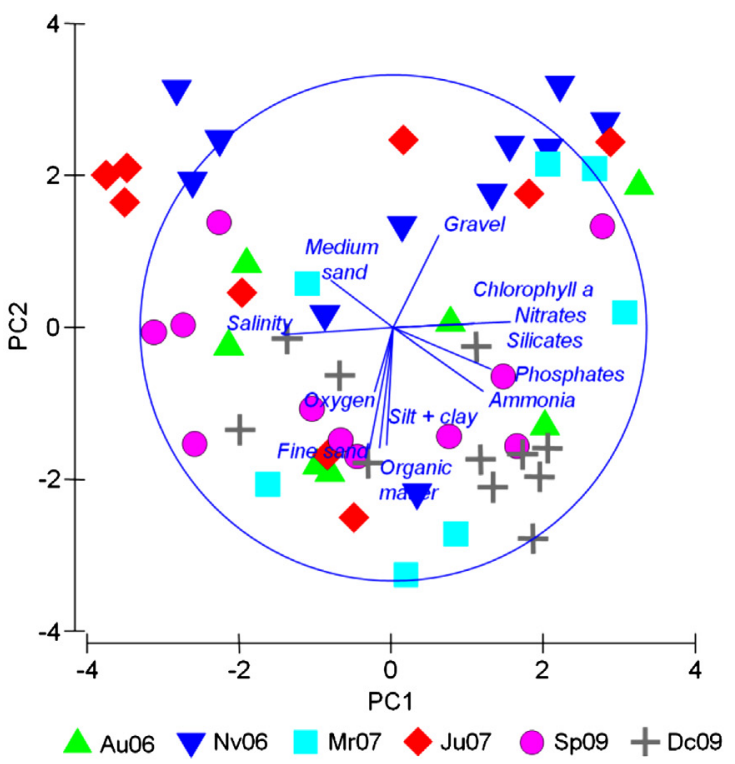

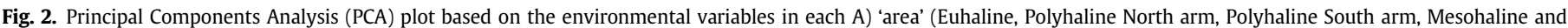

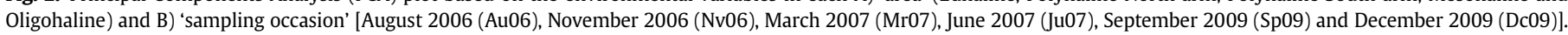
$\mathrm{PC} 1=32.8 \%$, PC2 $=28.0 \%$. 

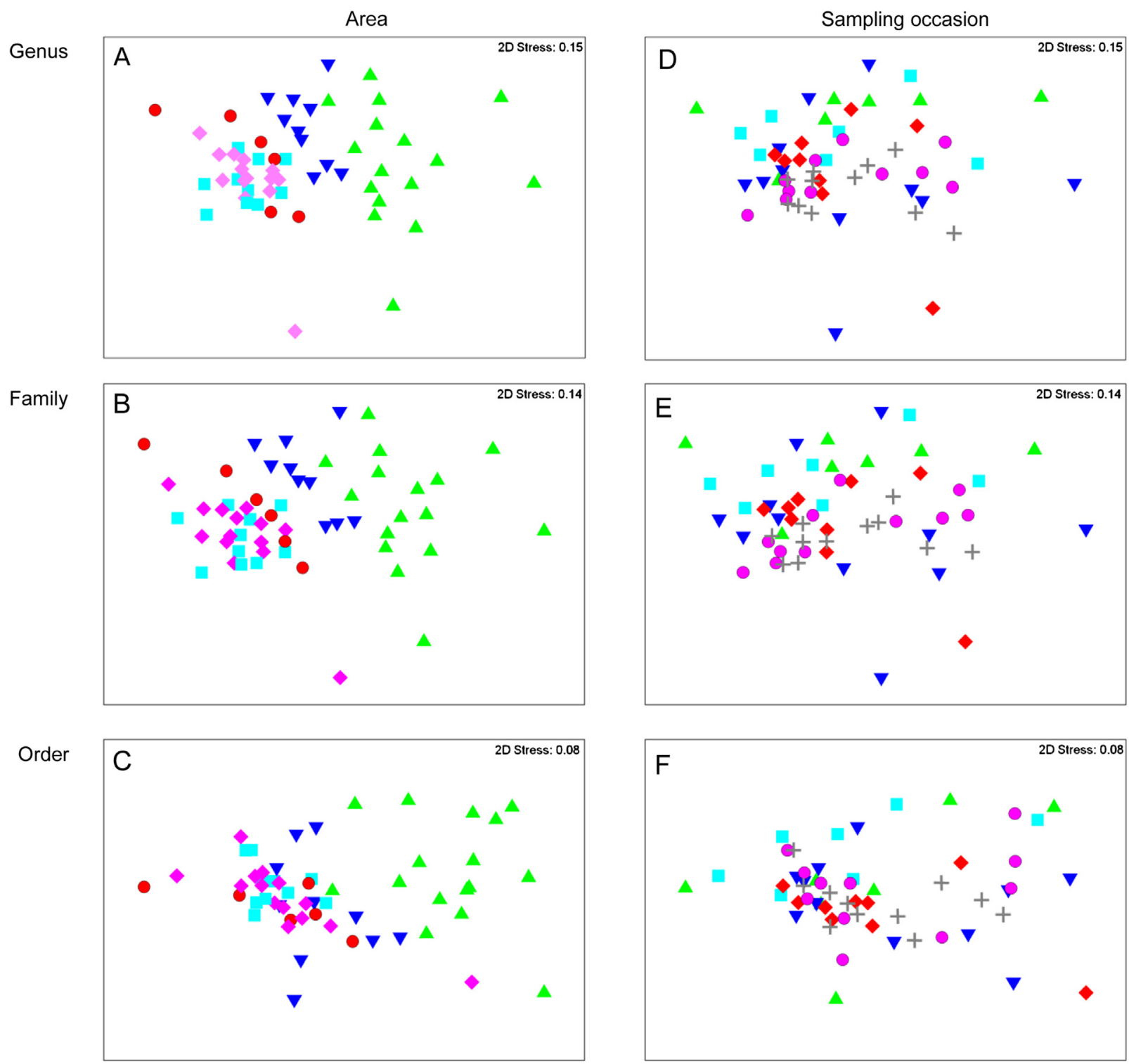

A Oligohaline $\nabla$ Mesohaline Polyhaline NA Polyhaline SA Euhaline

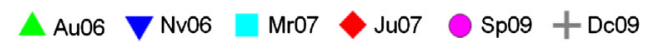

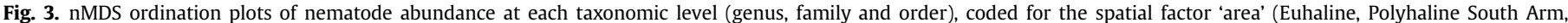

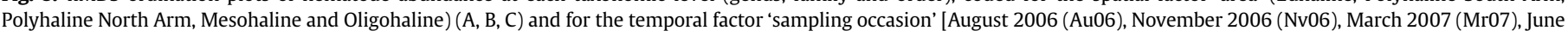
2007 (Ju07), September 2009 (Sp09) and December 2009 (Dc09)] (D, E, F).

\subsubsection{Environmental data}

A Principal Components Analysis (PCA) of the environmental variables was performed. The redundant variables were removed from the analysis so that the first two axis account for the maximum variability in the dataset. The variables retained in the model act as proxy for the ones that were eliminated. Prior to calculating the resemblance matrix using the Euclidean distance coefficient, variables were square root transformed (salinity, ammonia, chlorophyll $a$, silicates, organic matter, mean sand and gravel), to reduce the right asymmetry of data distribution (with the exception of dissolved oxygen) and then normalized. The relationships between environmental variables and the taxonomic (genus, family and order) and functional structure (single functional groups and combined biological traits matrix resulting from BTA) of nematode communities, were explored by carrying out BIOENV analyses (Clarke and Ainsworth, 1993). Spearman's rank correlations were used and a permutation test was applied to assess the significance of these relationships.

\subsubsection{Nematode assemblages}

Tests of spatial and temporal differences were carried out using two-way permutational multivariate analyses of variance (PERMANOVA). All PERMANOVA analyses were performed using a crossed factor experimental design: 'area' and 'sampling occasion' as fixed factors, with five (Euhaline, Polyhaline North arm, Polyhaline South arm, Mesohaline and Oligohaline) and six (August 2006, November 2006, March 2007, June 2007, September 2009 and December 2009) levels, respectively. The 'Permutation of residuals under a reduced model' option was selected and 9999 permutations carried out. When significant differences $(p<0.05)$ were detected, these were further examined using a posteriori pairwise comparisons. 
To visually assess spatial and temporal patterns, non-metric Multidimensional Scaling (nMDS) ordinations were carried out. Data were first square root transformed and the Bray-Curtis coefficient was the similarity coefficient used. The Similarity Percentage Analysis (SIMPER) was used to determine which taxa contributed most to similarity within areas and to dissimilarity between them (cut-off 75\%). Resemblance (correlation) matrices derived from each taxonomic level, single trait groups and multitrait matrix were then used in a second-stage nMDS analysis to examine similarities among each of the first-stage MDS matrices (Somerfield and Clarke, 1995), by means of Spearman's rank correlations.

\section{Results}

\subsection{Environmental variables}

The first two PCA axes accounted for $60.8 \%$ of the total variation (Fig. 2A and B). A clear separation of sampling areas was shown (Fig. 2A): the euhaline and polyhaline NA areas presented higher salinity and medium size particles diameter; the polyhaline SA was characterized by higher organic matter concentration and fine sediments whilst both mesohaline and oligohaline upstream areas were distinguished by higher nutrient concentration and chlorophyll $a$ concentration. In turn, temporal distinction was not evident (Fig. 2B) although samples from Sp09 and Dc09 presented mainly fine sediments, and high organic matter and nutrients concentrations. In summary, the spatial gradient appeared clearer than the temporal one.
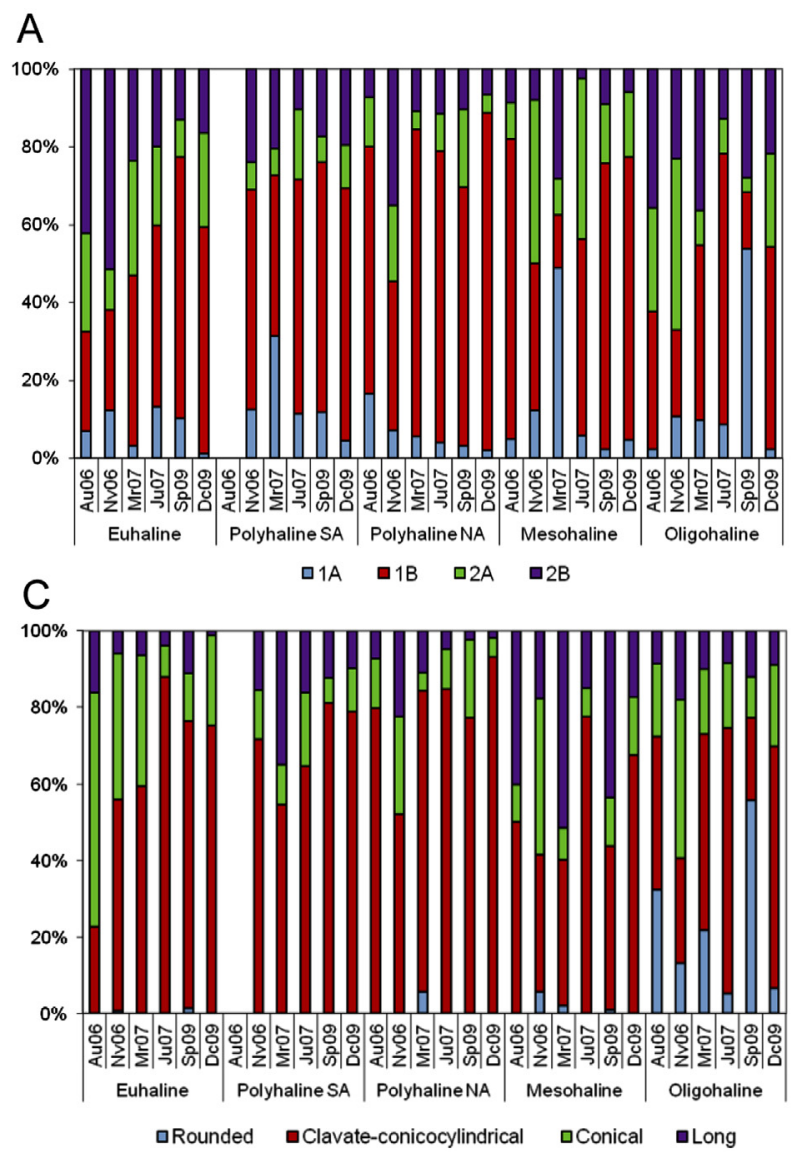

\subsection{Taxonomic classification}

When considering taxonomic classification, significant spatial and temporal differences at each level (genus, family and order) were detected by the two-way PERMANOVA (all $p<0.05$; Annex 2 and 3). A clear spatial segregation of the oligohaline and mesohaline areas from the remaining was observed in nMDS ordination plots regardless of the taxonomic level analysed (Fig. 3A-C), highlighting the particular species composition of the nematode assemblages inhabiting these areas. The SIMPER analysis (Annex 4) showed that these areas were mainly characterized by the genera Daptonema, Mesodorylaimus, Ptycholaimellus, Anoplostoma, Sabatieria, Dichromadora, Paracyatholaimus, Viscosia, Neotobrilus, Mononchus, Terschellingia, Plectus, Axonolaimus, Theristus and Eudorylaimus (oligohaline area), and Daptonema, Anoplostoma, Dichromadora, Terschellingia, Viscosia, Paracyatholaimus, Sabatieria, Ptycholaimellus, Sphaerolaimus and Leptolaimus (mesohaline area). In turn, the Euhaline area presented no significant differences in species composition over time for the various taxonomic levels. This section was mainly characterized by the genera Daptonema, Sabatieria, Viscosia, Sphaerolaimus, Linhomoeus, Oncholaimellus, Dichromadora, Anoplostoma, Terschellingia, Molgolaimus, Paracyatholaimus, Odontophora, Ptycholaimellus, Metachromadora, Halalaimus, Chromadorita and Microlaimus, belonging to the families Xyalidae, Comesomatidae, Oncholaimidae, Sphaerolaimidae, Linhomoeidae, Chromadoridae, Desmodoridae, Axonolaimidae, Anoplostomatidae and Cyatholaimidae. There was no obvious temporal pattern for each taxonomic level considered in assemblage composition Fig. 3D-F).
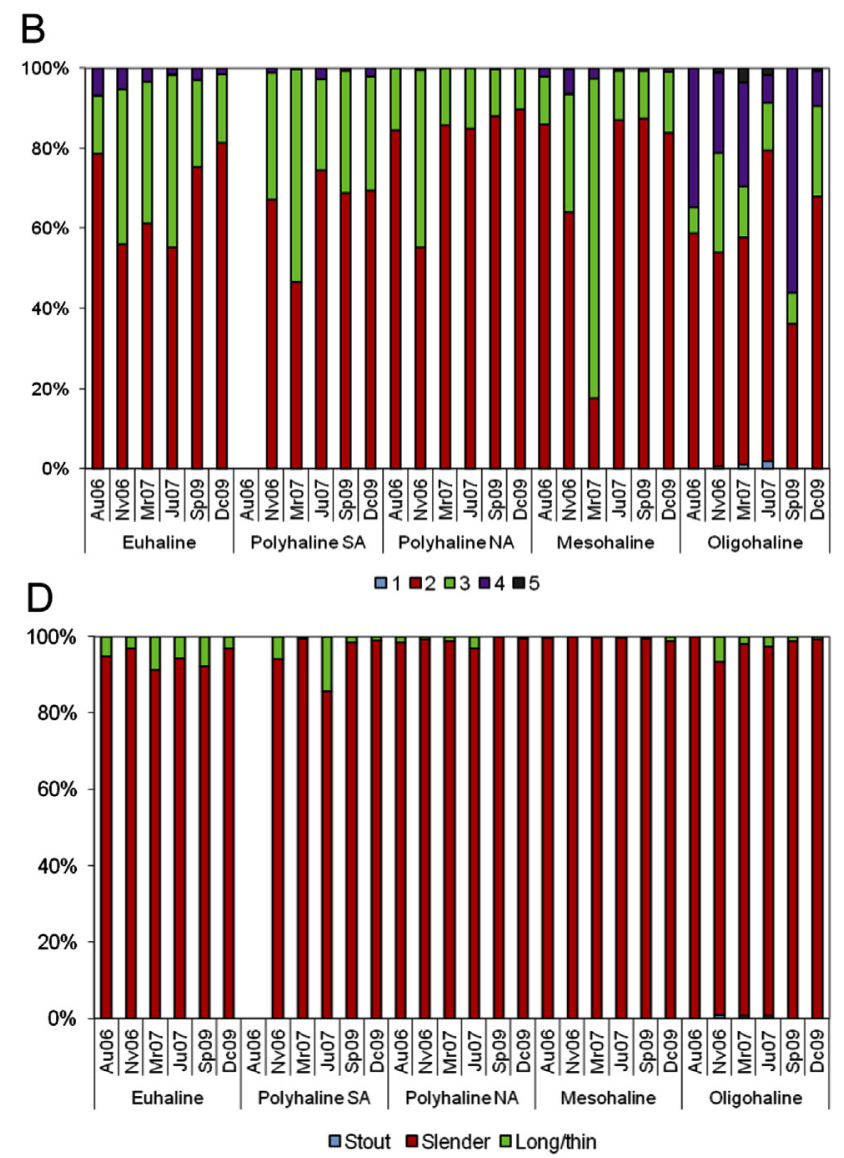

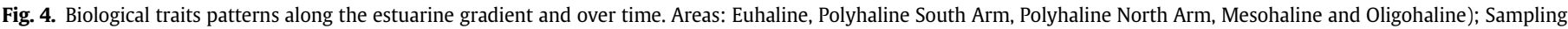

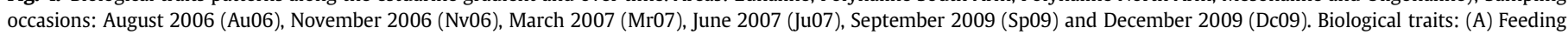
type, (B) Life strategy, (C) Tail shape and (D) Body shape. 

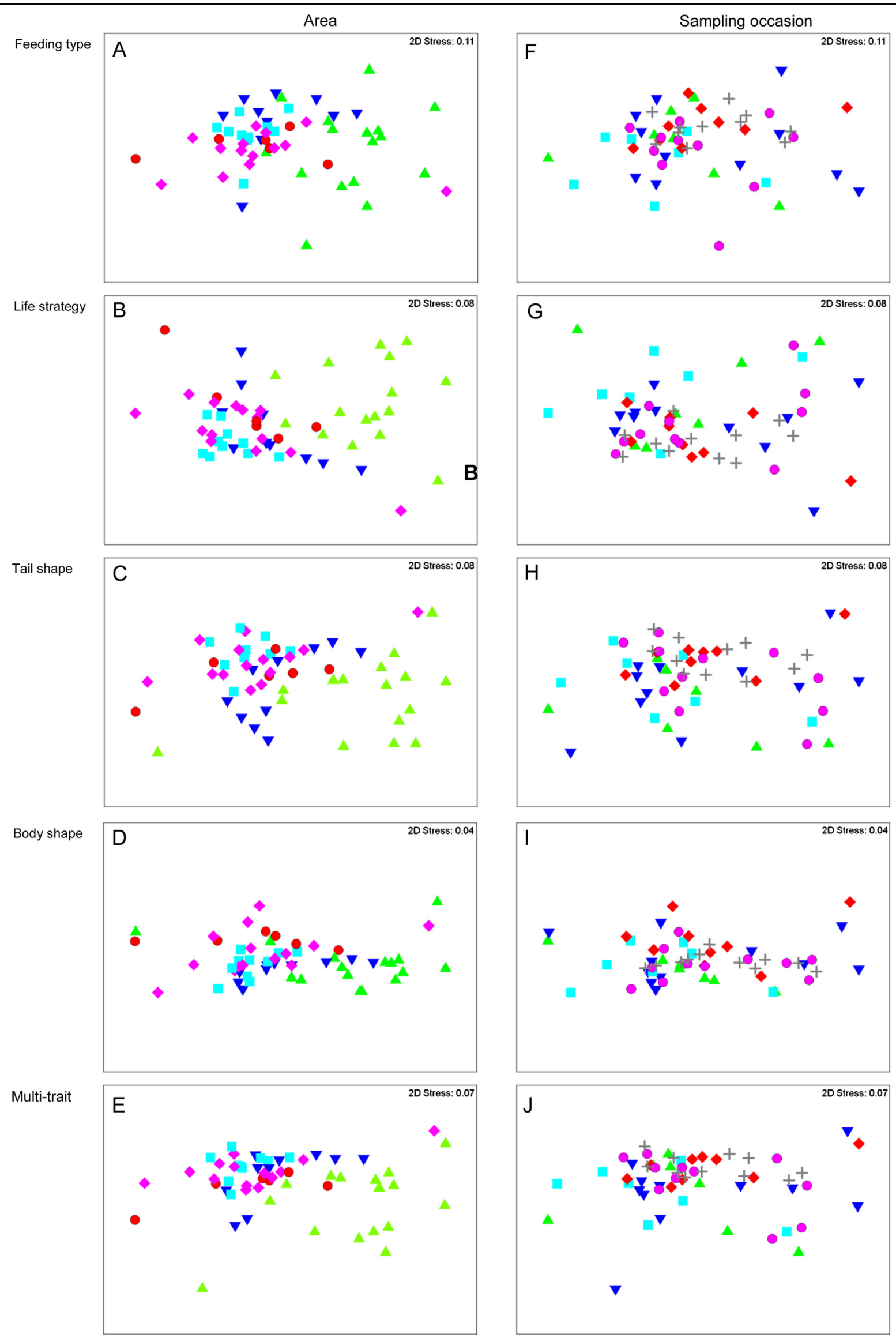

$\triangle \mathrm{Au06}$ Nv06 $\mathrm{Mr07} \diamond \mathrm{Ju07} \bigcirc \mathrm{Sp09}+\mathrm{Dc09}$

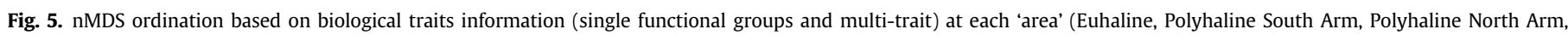

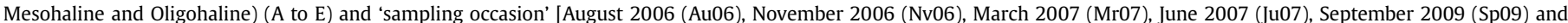
December 2009 (Dc09)] (F to J). 


\begin{tabular}{|ccc|}
\hline & & \\
Feeding type & 2D Stress: 0.01 \\
Body shape strategy & Family Genus \\
& Multi-trait & \\
& Tail shape & \\
\end{tabular}

Fig. 6. Second stage non-metric MDS plot of inter-matrix Spearman correlations among matrices of taxonomic levels (genus, family and order), single traits composition (feeding type, life strategy, tail shape and body shape) and multi-trait data.

\subsection{Biological traits: spatial and temporal patterns}

With regard to the biological traits characterizing each estuarine zone during the study period, the different traits varied in their spatial and temporal distribution (Fig. 4A-D). Overall, assemblages were dominated by non-selective deposit feeders (1B, 50.5\%) and omnivores/predators (2B, 20.9\%) (Fig. 4A). Most nematodes attained a colonizer-persister score of 2 or $3(\mathrm{cp}=2: 68.1 \%, \mathrm{cp}=3: 27.8 \%$ ), while scores of 1 or 5 were rare (Fig. 4B). Clavate-conicocylindrical and conical tails were the prevalent tail shapes $(55.8 \%$ and $23.2 \%$, respectively; Fig. 4C) and, from the three body shapes analysed, a predominance of slender bodies (96.7\%) was observed (only $3.2 \%$ of nematodes presenting long/thin bodies) (Fig. 4D). When considering the biological traits composition data, significant spatial and temporal differences for single traits and for the multi-trait approach were detected by the two-way PERMANOVA (Annex 1 and 2). It is of note that there were no temporal differences in the polyhaline NA area. These patterns can be observed in the nMDS plots, where the spatial segregation of the oligohaline area is visible (Fig. 5A-E) but with no obvious temporal patterns (Fig. 5F-J).

\subsection{Taxonomic and functional composition}

Combining the information from both taxonomic and functional approaches, the 2nd stage nMDS plot (Fig. 6) revealed that biological traits information differed from the taxonomic information, since biological traits clustered together, clearly separated from taxonomic levels. Multi-trait data clustered closest to single traits than to taxonomic levels data. Results from the BIOENV analyses showed that, although low correlation values were obtained, the distribution of nematodes at the different taxonomic levels was mainly related to salinity, nutrients and chlorophyll $a$. The main structuring factors of the trait distribution were salinity, oxygen, nitrates, grain size (fine sand and gravel) and chlorophyll $a$ (Table 1).

\section{Discussion}

By describing the taxonomic and functional structure of nematode assemblages in the Mondego estuary and by contrasting the information provided when using different approaches, the present study highlighted the importance of the estuarine spatial gradient in driving the distribution of the taxonomic and functional groups. To address the most relevant findings from the analysis of the subtidal nematode communities, this Discussion is divided according to the three main research questions initially posed.

\subsection{Taxonomic classification}

Taxonomic sufficiency has received much attention in assessment studies, especially in freshwater systems, mainly due to logistical difficulties, cost and time involved in species-level identification (Trigal-Domínguez et al., 2010). However, despite the advantages of a coarser resolution, in impact assessment studies and perturbation gradients a finer resolution can be desirable to reveal differences in the community structure (Trigal-Domínguez et al., 2010). The spatial and temporal analysis of the nematode assemblage data at different taxonomic levels in the Mondego estuary revealed a clear spatial segregation of the communities. Less obvious was the temporal effect on the distribution pattern of the communities. These findings agree with Alves et al. (2013) who gave a detailed account of the genus distribution patterns, diversity and community structure of the nematode communities in the Mondego estuary. A predominance of the spatial effect over the temporal one on the distribution patterns of assemblages was also observed. At both genus and family level, a clear separation of the upstream areas (mesohaline and oligohaline) was observed, due to the dominance of typical freshwater communities in these areas. On the other hand, at the order level, spatial differences were not clear.

Salinity is an important environmental factor influencing nematode distribution within the estuaries (Heip et al., 1985; Austen and Warwick, 1989; Soetaert et al., 1995). In this study, salinity together with sediment composition, were the most important abiotic factors distinguishing nematode genera and family patterns within the estuary. Fewer factors were important for describing order-level assemblage patterns.

Somerfield and Clarke (1995) have highlighted that analyses of sublittoral and intertidal nematode communities are robust to aggregation to the level of genus, but further aggregations starts to alter the perceived patterns of impact. Although no direct anthropogenic impact was analysed in the present study, the nematode distribution patterns along the estuarine natural gradient also revealed clear at lower taxonomic levels than order-level. Therefore, for this particular system, analyses using taxonomic resolutions at genus or family level seem advantageous to highlight community distribution patterns, which is important when implementing future management actions.

\subsection{Biological traits}

\subsubsection{Single traits}

The feeding characterization of nematodes confirmed, at the spatial level, the separation of the oligohaline area, mainly due to the high percentage of predators, from the remaining estuarine areas. With the exception of the euhaline area, where both nonselective deposit feeders (1B) and omnivores/predators (2B) were present at similar densities, non-selective deposit feeders dominated in each area and on various sampling occasions. Similar dominance patterns of non-selective deposit-feeders nematodes were observed by Schratzberger et al. $(2007,2008)$ in the North Sea. However, this dominance can be questionable since, according to several authors that have revised and modified Wieser's classification (Romeyn and Bouwman, 1983; Jensen, 1987; Moens and Vincx, 1997; Moens et al., 2004), confining species to a single trophic role may not represent the real plasticity in changing feeding strategies observed in several nematodes (Moens et al., 2005; Schratzberger et al., 2008) as a response to the complexity of the available feeding habitats (Moens and Vincx, 1997). Furthermore, 
Table 1

Results from BIOENV analyses: Spearman rank correlation (rho) and significance level $(p)$ between nematode data (taxonomic levels and biological traits) and environmental variables. Values in bold were significant at $p<0.05$.

\begin{tabular}{|c|c|c|c|}
\hline & rho & $p$ & Environmental variables \\
\hline Genus & 0.419 & 0.01 & $\begin{array}{l}\text { Nitrates, silicates, gravel, } \\
\text { chlorophyll } a\end{array}$ \\
\hline Family & 0.402 & 0.01 & $\begin{array}{l}\text { Oxygen, nitrates, silicates, gravel, } \\
\text { chlorophyll } a\end{array}$ \\
\hline Order & 0.352 & 0.01 & $\begin{array}{l}\text { Salinity, nitrates, silicates, fine sand, } \\
\text { chlorophyll } a\end{array}$ \\
\hline Feeding type & 0.228 & 0.02 & $\begin{array}{l}\text { Salinity, silt + clay, fine sand, gravel, } \\
\text { chlorophyll } a\end{array}$ \\
\hline Life strategy & 0.318 & 0.01 & $\begin{array}{l}\text { Salinity, nitrates, silt + clay, fine sand, } \\
\text { chlorophyll } a\end{array}$ \\
\hline Tail shape & 0.287 & 0.01 & $\begin{array}{l}\text { Salinity, oxygen, nitrates, fine sand, } \\
\text { chlorophyll } a\end{array}$ \\
\hline Body shape & 0.201 & 0.9 & Oxygen, nitrates \\
\hline Multi-trait & 0.282 & 0.01 & $\begin{array}{l}\text { Salinity, oxygen, nitrates, fine sand, } \\
\text { chlorophyll } a\end{array}$ \\
\hline
\end{tabular}

trophic plasticity has also been suggested as responsible for the absence of temporal relations between the trophic nematodes composition and food availability (chlorophyll $a$ or carbon sedimentation) (Schratzberger et al., 2008).

According to Bongers et al. (1991), the life strategy characterization provides important additional information to that given by the feeding types regarding disturbance. A different composition was observed in both euhaline and polyhaline SA areas, where a dominance of colonisers and intermediate ( $c-p 2$ and 3 ) taxa was registered, suggesting a high stress level with an increase of opportunistic genera. Higher abundance of coloniser nematodes was even more obvious at the polyhaline NA area, pointing to a disturbed condition. However, whether this high abundance of colonisers is caused by disturbance, increases in decomposition or in quantity of food (favouring fast-reproducing species) (Bongers et al., 1991) is not easily determined. Despite this, Moreno et al. (2011) suggested including $\mathrm{c}-\mathrm{p}$ class percentage as an ecological quality indicator, since reliable results regarding environmental conditions (previously defined in sediments of the Mediterranean sea) were obtained considering the different percentage composition of $\mathrm{c}-\mathrm{p}$ classes.

Assuming that similar shapes correspond, to a certain extent, to similar fitness constraints, morphometric characterization becomes a useful descriptor of ecosystems (Schwinghamer, 1983). Nematode tails play an important role in the locomotion, feeding and reproduction processes and morphological adaptations are characteristic of specific environments (Thistle and Sherman, 1985). The four types analysed showed a dominance of clavateconicocylindrical tails along the estuary, especially in the polyhaline areas, while long tails were abundant on the mesohaline area. Long tails were reported by Riemann (1974) for individuals that have a partly sessile existence in which tail morphology plays a crucial role, especially in sand (Ax, 1963) and muddy sediments (Riemann, 1974), enabling animals to retract from blocked interstitial passageways and forage for food. In agreement, this estuarine area was characterized by relatively small particle diameter (medium sand). The abundance of conical tails in the euhaline area points towards a different structure of the community. According to Thistle et al. (1995), insights based on tail shape give additional information to that incorporated by the buccal-morphology groups, making them potentially useful as ecological indicators.

Losi et al. (2013) found nematode body shape to be an informative parameter which was suggested to be related with the available food and biogeochemical conditions of the sediment (Tita et al., 1999; Soetaert et al., 2002; Vanaverbeke et al., 2004). This trait was the least informative regarding the separation of areas since slender bodies dominated in all areas and sampling occasions, not presenting any clear relation with the environmental factors analysed. However, stout nematodes appeared mainly in the oligohaline area, which can be related to the lower values of oxygen in this section. According to Soetaert et al. (2002), depth in the sediment influences the length and width of nematodes, being consistent with an adaptation to changing oxygen concentration, with nematode body width decreasing simultaneously, resulting in higher oxygen absorption efficiency. On the other hand, long/thin nematodes were found in the downstream areas (euhaline and polyhaline areas), which could be hypothesized to be related with a more unstable environment, since this body shape is thought to be advantageous for 'hanging' in high-energy or coarse-sediment habitats (Gerlach, 1953; Wieser, 1959; Warwick, 1971; Tietjen, 1976; Thistle and Sherman, 1985).

\subsubsection{Multi-trait}

Assigning the functional traits to each nematode genus may lead to a reduction of a generally high diversity into a small number of single functional groups (suggesting limited functional diversity), resulting in the underestimation of the true functional complexity of nematode communities (Thistle et al., 1995; Schratzberger et al., 2007). In turn, combining multiple biological traits expressed by the organisms has been considered a more reliable approach in assessing functional structure of nematode communities (Schratzberger et al., 2007).

The distribution pattern of the communities based on the BTA approach was similar to that observed with the single traits, although it has not proved to be a simple reflection of the information contained in the latter. Similar findings were also reported by Schratzberger et al. (2007) for nematode communities in the southwestern North Sea.

The merger of the functional features represents a more realistic approach, since different aspects of the functioning of the system are gathered. For instance, nematodes within the same trophic group present a wide range of life strategy categories and PostmaBlaauw et al. (2005) showed that differences in life history strategies between nematode species of the same trophic group is of importance for their communal effect on soil ecosystem processes.

Along the Mondego estuary, in addition to the main environmental variables that are known to influence nematodes distribution in the sediments (salinity and grain size), dissolved oxygen appeared an important factor related to community distribution. This variable is mostly referred as structuring the vertical profile of nematodes in the sediment, since the vertical distribution of diversity and density of nematodes is related with the penetration of dissolved oxygen (Soetaert et al., 1994; Coull, 1999). The recognition of dissolved oxygen as a structuring factor of nematode assemblage distribution in the Mondego estuary became most apparent when applying BTA. Since the most abundant genera found (Terschellingia, Sabatieria and Daptonema) are known to be typical of poorly oxygenated and organically enriched bottoms (Soetaert et al., 1994; Schratzberger et al., 2006; Steyaert et al., 2007), this suggests some degree of system disturbance.

The information on biological traits is still scarce for free-living nematodes and the affinity of each genus to each trait category is not easily assigned, as for macrobenthic communities. For the latter communities a wide range of information is available and the extent a species expresses each category (there might be variability with respect to traits that vary over species' life cycles or between populations - Bremner, 2008) can be defined, using procedures such as 'fuzzy coding' (Chevenet et al., 1994). Due to a lack of information on nematodes, equal weighting to all traits had to be considered in this study. As pointed out by Schratzberger et al. (2007), there is still a need for greater knowledge regarding 
functional roles of nematodes, which will help interrogate the sensitivity and interpretation of biological traits analyses.

\subsection{Taxonomic vs. functional approaches}

Despite the fact that different communities characterize different areas of the estuary and variation in the categories of each trait along the estuarine gradient have been observed, the dominance of some traits was consistent along the system, suggesting functional maintenance. According to Walker et al. (1999) and Warwick and Clarke (2001) changes in phylogenetic diversity of species assemblages are not explicitly linked to changes in functional diversity and so their ecological significance can be difficult to assess.

The biological traits approach, while of value, was no more powerful than the traditional taxonomic approach in detecting spatial differences along the Mondego estuary. Similar outcomes were observed by Schratzberger et al. (2007) for nematode assemblages in the North Sea and Armenteros et al. (2009) in the Caribbean Sea, where the inclusion of trait-based analyses provided additional information of community distribution patterns regarding different environmental factors. In the present study although the information obtained by the taxonomic approach was not superimposed on that obtained with the functional ones, the distribution patterns of the communities related to similar sets of environmental parameters. Nevertheless, trait-based approaches contributed to increase knowledge on the functional structure and characterization of nematode communities in the estuary.

The use of biological traits has been strongly encouraged in studies aiming at analysing diversity patterns (Armenteros et al., 2009) and assessing ecosystem functioning (Bremner et al., 2003). In this context, since trait-based approaches are known for their high robustness with decreased taxonomic resolution (Menezes et al., 2010), problems associated with misidentification can be less critical since nematode species with high morphological similarity will most probably share the same trait category.

\section{Conclusions}

A characterization of the traits structure was performed, for the first time, for the nematode communities of the Mondego estuary. No clear temporal pattern was observed in traits distribution and considering different taxonomic levels, while spatial differences were evident using both taxonomic and functional approaches. Genus and family identification level allowed similar outcomes regarding spatial differentiation of estuarine areas with a clear separation of the upstream oligohaline and mesohaline areas due to their particular species composition. The single-trait approach also highlighted the peculiarity of the upstream areas and the multi-trait approach emphasised the importance of specific environmental factors (oxygen and nutrients) on the distribution patterns of the nematode communities along the estuary. This shows the value of the application of traits-based methods, providing complementary types of information to that obtained by the classical taxonomic methods.

\section{Acknowledgements}

The present study was supported by the research projects 3MRECITAL (LTER/BIA-BEC/0019/2009) and DEVOTES (EU ENV.2012.6.2-3 - Grant agreement 308392; http://www.devotesproject.eu). It also had the support of the Fundação para a Ciência e a Tecnologia (FCT) (Pest-OE/MAR/UI0199/2011). A.S. Alves benefited from a PhD grant (SFRH/BD/62000/2009) from FCT (Portuguese Science and Technology Foundation). Authors would like to thank anonymous reviewers for the constructive comments that allowed us to improve the manuscript.

\section{Appendix A. Supplementary data}

Supplementary data related to this article can be found at http:// dx.doi.org/10.1016/j.ecss.2013.12.014.

\section{References}

Abebe, E., Traunspurger, W., Andrássy, I., 2006. Freshwater Nematodes: Ecology and Taxonomy. CABI Publishing, Oxfordshire, UK, p. 752.

Adão, H., Alves, A.S., Patrício, J., Neto, J.M., Costa, M.J., Marques, J.C., 2009. Spatial distribution of subtidal Nematoda communities along the salinity gradient in two Southern European estuaries (Portugal). Acta Oecologica 35, 287-300.

Alves, A.S., Adão, H., Ferrero, T.J., Marques, J.C., Costa, M.J., Patrício, J., 2013. Benthic meiofauna as indicator of ecological changes in estuarine ecosystems: the use of nematodes in ecological quality assessment. Ecol. Indic. 24, 462-475.

Anderson, M.J., Gorley, R.N., Clarke, K.R., 2008. PERMANOVA A+ for PRIMER: Guide to Software and Statistical Methods. PRIMER-E, Plymouth, UK.

Armenteros, M., Ruiz-Abierno, A., Fernández-Garcés, R., Pérez-García, J.A., DíazAsencio, L., Vincx, M., Decraemer, W., 2009. Biodiversity patterns of free-living marine nematodes in a tropical bay: Cienfuegos, Caribbean Sea. Estuar. Coast. Shelf Sci. 85, 179-189.

Austen, M.C., Warwick, R.M., 1989. Comparison of univariate and multivariate aspects of estuarine meiobenthic community structure. Estuar. Coast. Shelf Sci. 29, 23-42.

Ax, P., 1963. Die Ausbildung eines Schwanzfadens in der interstitiellen Sandfauna und die Venvertbarkeit von Lebensformcharakteren fiir die Verwandtschaftsformschung. Zool. Anz. 171, 51-76.

Bongers, T., 1990. The Maturity Index: an ecological measure of environmental disturbance based on nematode species composition. Oecologia 83, 14-19.

Bongers, T., Alkemade, R., Yeates, G.W., 1991. Interpretation of disturbance-induced maturity decrease in marine nematode assemblages by means of Maturity Index. Mar. Ecol. Prog. Ser. 76, 135-142.

Bremner, J., Rogers, S.I., Frid, C.L.J., 2003. Assessing functional diversity in marine benthic ecosystems: a comparison of approaches. Mar. Ecol. Prog. Ser. 254,11-25.

Bremner, J., Rogers, S.I., Frid, C.L.J., 2006a. Matching biological traits to environmental conditions in marine benthic ecosystems. J. Mar. Syst. 60, 302-316.

Bremner, J., Rogers, S.I., Frid, C.L.J., 2006b. Methods for describing ecological functioning of marine benthic assemblages using biological traits analysis (BTA). Ecol. Indic. 6, 609-622.

Bremner, J., 2008. Species' traits and ecological functioning in marine conservation and management. J. Exp. Mar. Biol. Ecol. 366, 37-47.

Brown, A.C., McLachlan, A., 1990. Ecology of Sandy Shores. Elsevier, Amsterdam.

Chalcraft, D.R., Resetarits, W.J., 2003. Mapping functional similarity of predators on the basis of trait similarities. Am. Nat. 162, 390-402.

Chevenet, F., Doledec, S., Chessel, D., 1994. A fuzzy coding approach for the analysis of long-term ecological data. Freshw. Biol. 31, 295-309.

Clarke, K.R., Ainsworth, M., 1993. A method of linking multivariate community structure to environmental variables. Mar. Ecol. Prog. Ser. 92, 205-219.

Clarke, K.R., Gorley, R.N., 2006. PRIMER v6: User Manual Tutorial. PRIMER-E Ltd., Plymouth, UK.

Coull, B.C., 1999. Role of meiofauna in estuarine soft-bottom habitats. Aust. J. Ecol. 24, 327-343.

Danovaro, R., Gambi, C., Dell'Anno, A., Corinaldesi, C., Fraschetti, S., Vanreusel, A., Vincx, M., Gooday, A., 2008. Exponential decline of deep-sea ecosystem functioning linked to benthic biodiversity loss. Curr. Biol. 18, 1-8.

Danovaro, R., Scopa, M., Gambi, C., Fraschetti, S., 2007. Trophic importance of subtidal metazoan meiofauna: evidence from in situ exclusion experiments on soft and rocky substrates. Mar. Biol. 152, 339-350.

Dauvin, J.C., 2007. Paradox of estuarine quality: benthic indicators and indices, consensus or debate for the future. Mar. Pollut. Bull. 55, 271-281.

de Jonge, V.N., Elliott, M., Brauer, V.S., 2006. Marine monitoring: its shortcomings and mismatch with the EU water framework directive's objectives. Mar. Pollut. Bull. 53, 5-19.

De Ley, P., Blaxter, M.L., 2004. A new system for the Nematoda: combining morphological characters with molecular trees, and translating clades into ranks and taxa. Nematol. Monogr. Perspect. 2, 633-653.

Ellis, D., 1985. Taxonomic sufficiency in pollution assessment. Mar. Pollut. Bull. 16, 459.

Flindt, M.R., Kamp-Nielsen, L., Marques, J.C., Pardal, M.A., Bocci, M., Bendoricchio, G., Salomonsen, J., Nielsen, S.N., Jørgensen, S.E., 1997. Description of three shallow estuaries: Mondego river (Portugal), Roskilde Fjord (Denmark) and the lagoon of Venice (Italy). Ecol. Model. 102, 17-31.

Frid, C.L.J., Rogers, S.I., Nicholson, M., Ellis, J.R., Freeman, S., 2000. Using biological characteristics to develop new indices of ecosystem health. In: Mini-symposium on Defining the Role of ICES in Supporting Biodiversity Conservation. ICES, Copenhagen, Denmark.

Gerlach, S.A., 1953. Die Biozonotische Gliederung der Nematodenfauna an den Deutschen Kusten. Z. Morphol. Okologie Tiere 41, 411-512.

Hooper, D.U., Chapin, F.S., Ewel, J.J., Hector, A., Inchausti, P., Lavorel, S., Lawton, J.H., Lodge, D.M., Loreau, M., Naeem, S., Schmid, B., Setala, H., Symstad, A.J., 
Vandermeer, J., Wardle, D.A., 2005. Effects of biodiversity on ecosystem functioning: a consensus of current knowledge. Ecol. Monogr. 75, 3-35.

Heip, C., Vincx, M., Vranken, G., 1985. The ecology of marine nematodes. Oceanogr. Mar. Biol.: Annu. Rev. 23, 399-489.

Jensen, P., 1987. Differences in microhabitat, abundance, biomass and body size between oxybiotic and thiobiotic free-living marine nematodes. Oecologia 71, $564-567$.

Kennedy, A.D., Jacoby, C.A., 1999. Biological indicators of marine environmental health: meiofauna - a neglected benthic component? Environ. Monit. Assess. 54, 47-68.

Limnologisk Metodik, 1992. In: Universitet Københavns (Ed.), Ferskvandsbiologisk Laboratorium. Akademisk Forlag, København, pp. 113-119.

Lorenzen, S., 1981. Entwurf eines phylogenetischen Systems der freilebenden Nematoden. Veröff. Inst. Meeresforsch. Bremerh. 7 (Supp.), 1-472.

Losi, V., Moreno, M., Gaozza, L., Vezzulli, L., Fabiano, M., Albertelli, G., 2013. Nematode biomass and allometric attributes as indicators of environmental quality in a Mediterranean harbour (Ligurian Sea, Italy). Ecol. Indic. 30, 80-89.

Lubchenco, J., 1998. Entering the century of the environment: a new social contract for science. Science 279, 491-497.

Marques, J.C., Maranhão, P., Pardal, M.A., 1993. Human impact assessment on the subtidal macrobenthic community structure in the Mondego Estuary (Western Portugal). Estuar. Coast. Shelf Sci. 37, 403-419.

Maurer, D., 2000. The dark side of taxonomic sufficiency (TS). Mar. Pollut. Bull. 40, 98-101.

Menezes, S., Baird, D.J., Soares, A.M.V.M., 2010. Beyond taxonomy: a review of macroinvertebrates trait-based community descriptors as tools for freshwater biomonitoring. J. Appl. Ecol. 47, 711-719.

Moens, T., Bouillon, S., Gallucci, F., 2005. Dual stable isotope abundances unravel trophic position of estuarine nematodes. J. Mar. Biol. Assoc. U. K. 85, 1401-1407.

Moens, T. Vincx, M., 1997. Observations on the feeding ecology of estuarine nematodes. J. Mar. Biol. Assoc. U. K. 77, 211-227.

Moens, T., Yeates, G.W., De Ley, P., 2004. Use of carbon and energy sources by nematodes. Nematol. Monogr. Perspect. 2, 529-545.

Moreno, M., Semprucci, F., Vezzulli, L., Balsamo, M., Fabiano, M., Albertelli, G., 2011. The use of nematodes in assessing ecological quality status in the Mediterranean coastal ecosystems. Ecol. Indic. 11, 328-336.

Parsons, T.R., Maita, Y., Lally, C.M., 1985. Pigments. In: A Manual of Chemical and Biological Methods for Seawater Analysis. Pergamon Press, pp. 101-104.

Platt, H.M., Warwick, R.M., 1983. Freeliving marine nematodes. Part I: British enoplids. Pictorial key to world genera and notes for the identification of British species. In: Synopses of the British fauna (New Series), vol. 28Cambridge University Press, Cambridge, p. 307.

Platt, H.M., Warwick, R.M., 1988. Freeliving marine nematodes. Part II: British chromadorids. Pictorial key to world genera and notes for the identification of British species. In: Synopses of the British fauna (New Series), vol. 38E.J. Brill, Leiden, p. 502.

Postma-Blaauw, M.B., de Vries, F.T., de Goede, R.G.N., Bloem, J., Faber, J.H. Brussaard, L., 2005. Within-trophic group interactions of bacterivorous nematode species and their effects on the bacterial community and nitrogen mineralization. Oecologia 142, 428-439.

R Development Core Team, 2009. R: a Language and Environment for Statistical Computing. R Foundation for Statistical Computing, Vienna, ISBN 3-900051-070. http://www.R-project.org.

Riemann, F., 1974. On hemisessile nematodes with flagelliform tail living in marine soft bottoms and on micro-tubes found in deep sea sediments. Mikrofauna Meeresbodens 40, 1-15.

Romeyn, K., Bouwman, L.A., 1983. Food selection and consumption by estuarine nematodes. Hydrobiol. Bull. 17, 103-109.

Schratzberger, M., 2012. On the relevance of meiobenthic research for policymakers. Mar. Pollut. Bull. 64, 2639-2644.

Schratzberger, M., Bolam, S., Whomersley, P., Warr, K., 2006. Differential response of nematode colonist communities to the intertidal placement of dredged material. J. Exp. Mar. Biol. Ecol. 334, 244-255.

Schratzberger, M., Forster, R.M., Goodsir, F., Jennings, S., 2008. Nematode community dynamics over an annual production cycle in the central North Sea. Mar. Environ. Res. 66, 508-519.

Schratzberger, M., Gee, J.M., Rees, H.L., Boyd, S.E., Wall, C.M., 2000. The structure and taxonomic composition of sublittoral meiofauna assemblages as an indicator of the status of the marine environment. J. Mar. Biol. Assoc. U. K. 80, 969980.
Schratzberger, M., Warr, K.J., Rogers, S.I., 2007. Functional diversity of nematode communities in the southwestern North Sea. Mar. Environ. Res. 63, 368-389.

Schwinghamer, P., 1983. Generating ecological hypotheses from biomass spectra using causal analysis: a benthic example. Mar. Ecol. Prog. Ser. 13, 151-166.

Soetaert, K., Muthumbi, A., Heip, C., 2002. Size and shape of ocean margin nematodes: morphological diversity and depth-related patterns. Mar. Ecol. Prog. Ser. 242, 179-193.

Soetaert, K., Vincx, M., Wittoeck, J., Tulkens, M., 1995. Meiobenthic distribution and nematode community structure in five European estuaries. Hydrobiologia 311, 185-206.

Soetaert, K., Vincx, M., Wittoeck, J., Tulkens, M., Van Gansbeke, D., 1994. Spatia patterns of Westerschelde meiobentos. Estuar. Coast. Shelf Sci. 39, 367-388.

Somerfield, P.J., Clarke, K.R., 1995. Taxonomic levels in marine community studies, revisited. Mar. Ecol. Prog. Ser. 127, 113-119.

Steyaert, M., Deprez, T., Raes, M., Bezerra, T., Demesel, I., Derycke, S., Desmet, G. Fonseca, G., Franco, M.A., Gheskiere, T., Hoste, E., Ingels, J., Moens, T. Vanaverbeke, J., Van Gaever, S., Vanhove, S., Vanreusel, A., Verschelde, D. Vincx, M., 2005. Electronic Key to the Free-living Marine Nematodes. http:// nemys.ugent.be/.

Steyaert, M., Garner, N., Van Gansbeke, D., Vincx, M., 1999. Nematode communities from the North Sea: environmental controls on species diversity and vertical distribution within the sediment. J. Mar. Biol. Assoc. U. K. 79, 253-264.

Steyaert, M., Moodley, L., Nadong, T., Moens, T., Soetaert, K., Vincx, M., 2007. Responses of intertidal nematodes to short-term anoxic events. J. Exp. Mar. Biol. Ecol. 345, 175-184.

Strickland, J.D.M., Parsons, T.R., 1972. A practical handbook of seawater analysis. In: Fisheries Research Board of Canada Bulletin, second ed.vol. 167. Fisheries Research Board of Canada, Ottawa, p. 311.

Teixeira, H., Salas, F., Borja, A., Neto, J.M., Marques, J.C., 2008. A benthic perspective in assessing the ecological status of estuaries: the case of the Mondego estuary (Portugal). Ecol. Indic. 8, 404-416.

Thistle, D., Lambshead, P.J.D., Sherman, K.M., 1995. Nematode tail-shape groups respond to environmental differences in the deep sea. Vie Milieu 45, 107-115.

Thistle, D. Sherman, K.M., 1985. The nematode fauna of a deep-sea site exposed to strong near-bottom currents. Deep-Sea Res. 32, 1077-1088.

Tietjen, J.H., 1976. Distribution and species diversity of deep-sea nematodes off North Carolina. Deep-Sea Res. 23, 755-768.

Tita, G., Vincx, M., Desroisiers, G., 1999. Size spectra, body width and morphotypes of intertidal nematodes: an ecological interpretation. J. Mar. Biol. Assoc. U. K. 79 1007-1015.

Trigal-Domínguez, C., Fernández-Aláez, C., García-Criado, F., 2010, Ecologica assessment of highly heterogeneous systems: the importance of taxonomic sufficiency. Limnologica 40, 208-214.

Vanaverbeke, J., Soetaert, K., Vincx, M., 2004. Changes in morphometric characteristics of nematode communities during a spring phytoplankton bloom deposition. Mar. Ecol. Prog. Ser. 273, 139-146.

Vanaverbeke, J., Steyaert, M., Vanreusel, A., Vincx, M., 2003. Nematode biomass spectra as descriptors of functional changes to human and natural impact. Mar. Ecol. Prog. Ser. 249, 17-157.

Vincx, M., 1996. Meiofauna in marine and freshwater sediments. In: Hall, G.S. (Ed.) Methods for the Examination of Organismal Diversity in Soils and Sediments. Cab International, Wallinfort, UK, pp. 187-195.

Walker, B., Kinzing, A., Landridge, J., 1999. Plant attribute diversity, resilience, and ecosystem function: the nature and significance of dominant and minor species. Ecosystems 2, 95-113.

Warwick, R.M., 1971. Nematode associations in the Exe estuary. J. Mar. Biol. Assoc. U. K. 51, 439-454.

Warwick, R.M., 1988. Analysis of community attributes of the macrobenthos of Frierfjord/Langesundfjord at taxonomic levels higher than species. Mar. Ecol. Prog. Ser. 46, 167-170.

Warwick, R.M., Clarke, K.R., 2001. Practical measures of marine biodiversity based on relatedness of species. Oceanogr. Mar. Biol.: Annu. Rev. 39, 207-231.

Warwick, R.M., Platt, H.M., Sommerfield, P.J., 1998. Free-living nematodes (Part III) Monhysterids. In: Barnes, Crothers (Eds.), Synopsis of British Fauna, 53.

Wieser, W., 1953. Die Beziehung zwischen Mundhöhlengestalt, Ernährungswiese und 1000 Vorkommen bei freilebenden marinen Nematoden. Ark. für Zool. 4 439-484.

Wieser, W., 1959. Free-living marine nematodes. IV. General part. Lunds Universitets Arsskrift, Avdelningen 2: Kungliga Fysiografiska Salskapets i Lund. Handlinger 55 (5), 1-109. 